\title{
Financial Performance Analysis of SMEs Before and After Initial Public Offering (IPO) on
} the Indonesia Stock Exchange (IDX)

\author{
Budi Wahyono
}

Department of Economics Education, Universitas Sebelas Maret

Email: budiwahyono@staff.uns.ac.id

\begin{tabular}{ll}
\hline Article Info & \multicolumn{1}{c}{ Abstract } \\
\hline $\begin{array}{l}\text { DOI: } \\
\text { http://dx.doi.org/10.2 }\end{array}$ & $\begin{array}{l}\text { SMEs still face funding constraints. IPO is one of the efforts that can be } \\
\text { done by SMEs to face this constraint. However, it is not yet known } \\
\text { whether the financial performance of SMEs will increase after conducting } \\
\text { an IPO. This study aims to analyze the financial performance of SMEs } \\
\text { before and after the IPO. The sample of this study is SMEs that listed on } \\
\text { the IDX in 2017, which is as many as five SMEs. SMEs financial }\end{array}$ \\
$\begin{array}{l}\text { Public Offering } \\
\text { (IPO), Small and }\end{array}$ & $\begin{array}{l}\text { performance is measured through three SMEs financial ratios, namely } \\
\text { Medium Enterprises } \\
\text { liquidity, solvability, and profitability. The paired sample t-test was used }\end{array}$ \\
$\begin{array}{l}\text { Performance, } \\
\text { to compare the financial performance of SMEs before and after the IPO. }\end{array}$ & $\begin{array}{l}\text { The results showed that there is no significant difference in the financial } \\
\text { performance of SMEs before and after the IPO. The results of this study } \\
\text { provide recommendations for further research related to the valuation and } \\
\text { performance of SME IPOs. }\end{array}$ \\
\hline
\end{tabular}

\section{INTRODUCTION}

Small and Medium Enterprises (SMEs) are an important sector in economic development in Indonesia. Based on data from the Ministry of Cooperatives and SMEs, it is known that in 2013 SMEs in Indonesia contributed $56.2 \%$ to the value of the national investment (OECD, 2018). In the range of 2009-2013, the contribution of SMEs to GDP reached 57.5\% (Bappenas, 2016). Although SMEs play a significant role in Indonesia's economic growth, there are still several obstacles faced, one of which is funding constraints.

Based on data from The Financial Services Authority (OJK), it is known that most SMEs credit needs have not been met (Rahayu, 2017). Banking data in 2015 shows that only 27, 4\% of SMEs in Indonesia have credit in banks (OECD, 2018), there are even around 60-70\% of MSMEs that do not have access to bank financing (LPPI, 2015). The government has tried to overcome this problem, one of which is through the People's Business Credit (KUR) program. However, the KUR program is only for micro and small businesses, even though the medium business sector also needs funding.

To meet this funding need, SMEs are encouraged to conduct IPOs on the Indonesia Stock Exchange (IDX). OJK has issued Regulations Number 53 / POJK.04 / 2017 and 54 / POJK.04 / 2017 to facilitate SMEs in conducting IPOs on the IDX. This OJK regulation is able to increase the number of SMEs conducting IPOs. The results of previous studies indicate that several measures of the company's financial performance have increased after conducting an IPO (Khatami, Hidayat \& 
Sulasmiyati, 2017). Yunanto and Daryono (2014) state that the ability of SMEs to generate profits does not experience significant changes after conducting an IPO. Another study was conducted by Pastusiak, Bolek, Malaczewski, \& Kacprzyk (2016) which stated that the company's ability to generate profits actually declined after conducting an IPO.

\section{Research Question}

The number of SMEs that conducted IPO showed a positive trend (increasing) after the issuance of the OJK Regulation No. 53 and 54 / PJOK.04 / 2017. However, will the SME's financial performance increase after conducting an IPO? To answer this question, research is needed on the analysis of SME financial performance before and after conducting an IPO on the IDX. Khatami's research, Hidayat \& Sulasmiyati (2017) focuses on the financial performance of non-financial companies, not SMEs. Research by Yunanto and Daryono (2014) only measures differences in the ability of SMEs to generate profits.

\section{RESEARCH METHOD}

\section{Population and Samples}

The population of this study was all SMEs that conduct IPOs on the IDX, while the sample was SMEs listing in 2017. The sampling technique used was purposive sampling with the consideration that in 2017 two regulations of OJK was issued, which regulates SMEs going public, namely the Financial Services Authority Regulation Number 53 / POJK.04 / 2017 and the Financial Services Authority Regulation Number 54 / POJK.04 / 2017. The basis for determining companies included in SMEs is companies that have total assets of not more than fifty billion rupiahs (for small scale companies) and have total assets of more than fifty billion rupiahs up to two hundred fifty billion rupiahs (for medium-scale companies). Based on these considerations, a sample of six small and medium enterprises (SMEs) was obtained. However, because there is one company whose financial statements are incomplete, only five companies are used as research samples.

\section{Operational Definition of Variables}

This study uses secondary data, namely in the form of company financial reports published on the IDX. The variable of this research is several ratios to measure the company's financial performance, namely liquidity, solvability, and profitability. The operational definition of each ratio is shown in table 1 .

Table 1. Operational Definition of Variables

\begin{tabular}{|c|c|c|c|c|}
\hline No & SMEs Financ & 1 Ratio & Formula & Operational Definition \\
\hline \multirow[t]{2}{*}{1} & \multirow[t]{2}{*}{ Liquidity } & Current Ratio & $\begin{array}{l}\text { Current Assets / Current } \\
\text { Liabilities }\end{array}$ & \multirow[t]{2}{*}{$\begin{array}{l}\text { The ability of SMEs to fulfill } \\
\text { short-term liabilities }\end{array}$} \\
\hline & & Quick Ratio & $\begin{array}{l}\text { [Current Assets - } \\
\text { Inventories] / Current } \\
\text { Liabilities }\end{array}$ & \\
\hline 2 & Solvability & & Total Debt / Total Assets & $\begin{array}{l}\text { The ability of SMEs to fulfill } \\
\text { their total debt }\end{array}$ \\
\hline \multirow[t]{3}{*}{3} & \multirow[t]{3}{*}{ Profitability } & Profit Margin & Net Profit / Sales & \multirow{3}{*}{$\begin{array}{l}\text { The company's ability to } \\
\text { generate profits }\end{array}$} \\
\hline & & $\begin{array}{l}\text { Return On Asset } \\
\text { (ROA) }\end{array}$ & Net Profit / Total Assets & \\
\hline & & $\begin{array}{l}\text { Return On } \\
\text { Equity (ROE) }\end{array}$ & $\begin{array}{l}\text { Net Income / Share } \\
\text { Capital }\end{array}$ & \\
\hline
\end{tabular}

Source: Hanafi (2015) \& Riyanto (2012)

\section{Data Analysis Technique}

The company's financial performance is measured based on the financial ratios of each company (as formulated in table 1). If the company's financial ratios before and after the IPOs are obtained, then a 
different test is carried out by paired sample t-test. This different test was conducted to analyze differences in the company's financial performance before and after the IPO.

\section{RESULTS AND DISCUSSION \\ Data Description}

Data on the financial performance of SMEs before and after listing (IPO) in 2017 are calculated based on the company's financial statements published on the IDX. The company's financial performance is measured based on liquidity ratios, solvability, and profitability. The description of SME financial performance data which includes measures of central tendency and dispersion is shown in table 2 .

Table 2. Data Description of SMEs Financial Performance Before and After IPO

\begin{tabular}{|c|c|c|c|c|c|c|}
\hline \multirow{3}{*}{ Variable } & \multicolumn{6}{|c|}{ SMEs Financial Performance Before the IPO } \\
\hline & \multicolumn{3}{|c|}{ Central Tendency } & \multicolumn{3}{|c|}{ Dispersion } \\
\hline & Mean & Median & Mode & Min & Max & Sta dev \\
\hline Current Ratio & 2,0266 & 1,0442 & 0,3814 & 0,3814 & 6,7016 & 2,6285 \\
\hline Quick Ratio & 1,6228 & 0,6515 & 0,3144 & 0,3144 & 6,1091 & 2,5126 \\
\hline Solvability & 0,7787 & 0,6974 & 0,0298 & 0,0298 & 1,6044 & 0,5867 \\
\hline Profit Margin & $-0,1367$ & $-0,1562$ & $-0,4404$ & 0,2269 & $-0,4404$ & 0,0945 \\
\hline ROA & $-0,0843$ & $-0,0228$ & $-0,3160$ & 0,1866 & $-0,3160$ & 0,1146 \\
\hline ROE & 2,0309 & 0,2429 & $-0,0235$ & 4,1116 & $-0,0235$ & 9,3808 \\
\hline \multirow{3}{*}{ Variable } & \multicolumn{6}{|c|}{ SMEs Financial Performance After the IPO } \\
\hline & \multicolumn{3}{|c|}{ Central Tendency } & \multicolumn{3}{|c|}{ Dispersion } \\
\hline & Mean & Median & Mode & Min & Max & Sta dev \\
\hline Current Ratio & 3,8752 & 1,9632 & 1,5470 & 1,5470 & 10,7034 & 3,8717 \\
\hline Quick Ratio & 3,1535 & 1,3171 & 0,6368 & 0,6368 & 10,2927 & 4,0347 \\
\hline Solvability & 0,3428 & 0,2948 & 0,0291 & 0,0291 & 0,5804 & 0,2339 \\
\hline Profit Margin & $-0,1482$ & $-0,1767$ & $-0,2439$ & $-0,2439$ & 0,2447 & 0,1747 \\
\hline ROA & 0,0299 & $-0,0164$ & $-0,0215$ & $-0,0215$ & 0,1936 & 0,0927 \\
\hline ROE & 0,0433 & $-0,0169$ & $-0,0483$ & $-0,0483$ & 0,2746 & 0,1329 \\
\hline
\end{tabular}

Source: secondary data processed (2018)

\section{Prerequisite Test for Analysis}

Before doing a paired sample t-test, the normality test is done first. The Kolmogorov Smirnov method was used for normality testing in this study. The results of the normality test are shown in table 3 below:

Table 3. The Normality Test

\begin{tabular}{|c|c|c|c|}
\hline & & $\begin{array}{c}\text { SMEs Financial Performance } \\
\text { Before the IPO }\end{array}$ & $\begin{array}{c}\text { SMEs Financial Performance } \\
\text { After the IPO }\end{array}$ \\
\hline \multicolumn{2}{|l|}{$\mathrm{N}$} & 6 & 6 \\
\hline Normal & Mean & 1,03966167 & 1,24502117 \\
\hline Parameters ${ }^{\mathrm{a}, \mathrm{b}}$ & Std. Deviation & 1,001238469 & 1,790890270 \\
\hline Most Extreme & Absolute & ,220 & ,359 \\
\hline \multirow[t]{2}{*}{ Differences } & Positive & 203 & ,359 \\
\hline & Negative &,- 220 &,- 241 \\
\hline \multicolumn{2}{|c|}{ Kolmogorov-Smirnov Z } & ,539 &, 880 \\
\hline \multicolumn{2}{|c|}{ Asymp. Sig. (2-tailed) } & 934 & ,420 \\
\hline
\end{tabular}

Source: secondary data processed (2018)

Based on table 3, it is known that the statistical value of SME financial performance before and after the IPO is above the level of significance ( $p>5 \%$ ). This shows that the sample of this study came from a population that was normally distributed. 


\section{Paired Sample t-test}

Paired sample t-test was used to analyze differences in the financial performance of SMEs before and after the IPO on the IDX. The paired sample t-test results are shown in tables 4 and 5.

Table 4. Average of Each SME Financial Performance Ratio Before and After IPO

\begin{tabular}{clll}
\hline No & Variable & Mean Before IPO & Mean After IPO \\
\hline 1 & Current Ratio & 2,02734 & 3,23660 \\
2 & Quick Ratio & 1,69086 & 2,66851 \\
3 & Solvability & 0,98743 & 0,29293 \\
4 & Profit Margin & 0,22450 & $-0,00513$ \\
5 & ROA & 0,26818 & 0,03219 \\
6 & ROE & 2,03093 & 0,04333 \\
\hline
\end{tabular}

Source: secondary data processed (2018)

Table 4 shows the difference in the average financial ratio of SMEs before and after the IPO. The significance of this difference is seen from the results of the analysis shown in table 5.

Table 5. Results of Paired Sample t-test

\begin{tabular}{cllll}
\hline No & Variable & $\mathrm{t}$ & Sig (2-tailed) & Test Decision \\
\hline 1 & Current Ratio & $-1,15$ & 0,211 & There is no significant difference \\
2 & Quick Ratio & $-1,433$ & 0,302 & There is no significant difference \\
3 & Solvability & 2,129 & 0,087 & There is no significant difference \\
4 & Profit Margin & 0,638 & 0,552 & There is no significant difference \\
5 & ROA & 0,664 & 0,536 & There is no significant difference \\
6 & ROE & 1,322 & 0,243 & There is no significant difference \\
\hline
\end{tabular}

Source: secondary data processed (2018)

The sig (2-tailed) value of all variables is greater than $5 \%$, this indicates that there is no significant difference between the financial performance of SMEs before and after conducting an IPO on the IDX.

\section{Discussion}

The financial performance of SMEs can be seen through various financial ratios. The results of the analysis show that the average financial ratio of SMEs has changed from before conducting an IPO after conducting an IPO. Table 4 shows the changing trends of each SME financial ratio before and after the IPO. There are several financial ratios that show trends in positive change (increasing) such as liquidity ratios (current ratio and quick ratio). The liquidity ratio is used to measure how much the ability of SMEs to guarantee loans with assets/assets owned. After conducting an IPO, the ability of SMEs to guarantee their loans with their assets has increased, although this increase has not been significant.

In the solvability ratio showing a negative trend (decreasing), this means that the percentage of SME debt has decreased after conducting an IPO, even though the decline is not significant. The same thing (downward trend) also occurs in the profitability ratio of SMEs. After conducting an IPO, the profitability ratio of SMEs declined. Decreasing profitability ratios indicate the ability of SMEs to generate profits has decreased, although the decline is not significant.

\section{CONCLUSION}

Changes occurred in SME financial performance before and after the IPO. These changes are seen in the increase in SME liquidity ratios and decrease in solvability and profitability ratios, even though these changes are not significant. This shows that after conducting an IPO on the IDX, the financial performance of SMEs did not experience significant changes. The results of this study provide recommendations for further research related to the valuation and performance of SME IPOs. 


\section{REFERENCE}

Bappenas (2016). Warta KUKM: Penguatan UMKM untuk Pertumbuhan Ekonomi yang Berkualitas. Jakarta: Direktorat Pengambangan UKM dan Koperasi, Kementerian PPN/Bappenas.

Hanafi, Mamduh M. (2008). Manajemen Keuangan. Yogyakarta: BPFE.

Khatami, N.; Hidayat, R.R.; \& Sulasmiyati, S. (2017). Analisis Kinerja Keuangan Perusahaan Sebelum dan Sesudah Initial Public Offering (IPO) di Bursa Efek Indonesia (Studi pada Perusahaan Non Finansial yang Listing di BEI Tahun 2011). Jurnal Administrasi Bisnis (JAB) Vol. 47 No. 1 Juni 2017.

LPPI (2015). Profil Bisnis Usaha Mikro, Kecil dan Menengah (UMKM). Kerjasama Lembaga Pengembangan Perbankan Indonesia dengan Bank Indonesia.

OECD (2018). SME and Entrepreneurship Policy in Indonesia 2018. OECD Studies on SMEs and Entrepreneurship. OECD Publishing. Paris. https://doi.org/10.1787/9789264306264-en.

Pastusiak, R.; Bolek, M.; Malaczewski, M. \& Kacprzyk, M. (2016) Company Profitability Before and After IPO. Is It a Windows Dressing or Equity Dilution Effect? Prague Economic Papers Volume 25, Issue 1, 2016, Pages 112-124. DOI: https://doi.org/10.18267/j.pep.540.

Peraturan Otoritas Jasa Keuangan Nomor 53 /POJK.04/2017 tentang Pernyataan Pendaftaran Dalam Rangka Penawaran Umum dan Penambahan Modal dengan Memberikan Hak Memesan Efek Terlebih Dahulu oleh Emiten Dengan Aset Skala Kecil atau Emiten dengan Aset Skala Menengah.

Peraturan Otoritas Jasa Keuangan Nomor 54 /POJK.04/2017 tentang Bentuk dan Isi Prospektus Dalam Rangka Penawaran Umum dan Penambahan Modal dengan Memberikan Hak Memesan Efek Terlebih Dahulu oleh Emiten dengan Aset Skala Kecil atau Emiten dengan Aset Skala Menengah.

Rahayu, N. (2017). UMKM Indonesia Kekurangan Pendanaan Hingga Rplo00 Triliun Setiap Tahunnya. https://www.wartaekonomi.co.id/read165490/umkm-indonesia-kekuranganpendanaan-hingga-rp1000-triliun-setiap-tahunnya.html.

Riyanto, B. (2012). Dasar-Dasar Pembelanjaan Perusahaan: Edisi 4. Yogyakarta: BPFE.

Yunanto, A. \& Daryono (2014). Analisis Komparasi Profitabilitas UKM Sebelum dan Sesudah Go Publik di Bursa Efek Indonesia. JP FEB Unsoed Vol. 4 No. 1 (2014). 